\title{
Factors Influencing to Customer Loyalty Towards Mobile Service Provider
}

\author{
Oleh: \\ Febriana Valentiony Alamsyah ${ }^{1}$, Indira Rachmawati ${ }^{2}$ \\ ${ }^{1}$ International ICT Business, Faculty of Economics and Business, Telkom University, \\ ${ }^{2}$ Faculty of Economics and Business, Telkom University \\ E-mail: ${ }^{1}$ febrianava@ student.telkomuniversity.ac.id, \\ 2indira.rachmawati@telkomuniversity.ac.id
}

\begin{abstract}
ABSTRAK
Penggunaan ponsel sebagai pendukung kehidupan telah membuat industri telekomunikasi tumbuh semakin besar. Fitur yang ditawarkan oleh smartphone beragam, mulai dari layanan panggilan reguler hingga beberapa aplikasi yang bisa membantu orang melakukan hal dengan mudah. Fenomena baru ini telah membuat persaingan antar penyedia layanan mobile semakin ketat. Mereka bersaing untuk mendapatkan sebanyak mungkin pelanggan dan mereka juga ingin mempertahankan pelanggan setia mereka saat ini. Penelitian ini bertujuan untuk mengetahui faktor-faktor yang mempengaruhi loyalitas pelanggan. Penelitian ini meneliti pengaruh kualitas layanan mobile terhadap kepuasan pelanggan melalui kepercayaan pelanggan dan keintiman pelanggan terhadap loyalitas pelanggan. Sebanyak 400 orang di Indonesia yang didapat dari rumus slovin telah diperiksa untuk mengetahui faktor-faktor yang mempengaruhi loyalitas pelanggan. Semua variabel yang diajukan semuanya diterima secara positif dan kepuasan pelanggan sangat berpengaruh terhadap kepercayaan pelanggan.
\end{abstract}

Kata Kunci: Loyalitas Pelanggan, Kualitas Pelayanan, Penyedia Layanan Mobile

\section{ABSTRACT}

The use of cellphones as life support has made the telecommunications industry grow bigger. The features offered by smartphones vary, ranging from regular call services to several applications that can help people do things easily. This new phenomenon has made competition between mobile service providers increasingly stringent. They compete to get as many customers as possible and they also want to retain their current loyal customers. This study aims to determine the factors that influence customer loyalty. This study examines the effect of the quality of mobile services on customer satisfaction through customer trust and customer intimacy towards customer loyalty. As many as 400 people in Indonesia obtained from the Slovin's formula have been examined to determine the factors that influence customer loyalty. All submitted variables are all positively accepted and customer satisfaction greatly influences customer trust.

Key Words: Customer Loyalty, Service Quality, Mobile Service Provider

\section{INTRODUCTION}

This new era has make the telecommunication service provider customers' increasing year by year. Indonesia has 250 million citizens, but there are around 300 million mobile phone users because of the tendency of use more than one mobile phone among Indonesian citizen (Katadata, 2016). Large population in Indonesia has made Indonesia as the most crowded cellular telecommunication market (ICLG, 2017).

Mobile phone is not categorized as a luxury goods anymore, it has become a primary need for most people. The mobile phone users in Indonesia keep increasing, but the number of cellular operator in Indonesia has decreasing in the past years. Now, telecommunication 
Industry in Indonesia is dominated by four big names such as Telkomsel, Indosat, 3, and XL Axiata.

The few of the player has made the competition even tighter. Telkomsel is one of the providers that has the most subscribers and followed by Indosat Ooredoo in the second place, 3 in the third place, and XL Axiata in the fourth place (Buol, 2017). In this digital era people are tend to use internet to connect with people, for example they tend to use instant messaging application rather than a conventional SMS because they think that if they use internet data it will be more advantageous.

The price that provides by those four companies are different. Telkomsel has price range of internet data from Rp.25.000 - Rp.210.000, XL Axiata's range is between Rp.12.000 - Rp.120.000, Indosat price is between Rp.2.900 - Rp.199.900, 3 range is from Rp.1.500 - Rp.150.000 (TeknoRus, 2017). Those price range are price for one-day package to monthly package. GSM operators are competing to gain as much customers as possible by looking at the opportunity that they can do. One of the opportunities is to provide the best quality product for the customer. They want the customer to be satisfied, so they can trust them and feel the intimacy among them. Those are several things that may affect customer loyalty. In order to gain customer loyalty, the company should know what are the factors that really influencing to customer loyalty.

\section{THEORETICAL BASIS}

\subsection{Service Quality}

Service quality is one of the factors that may influencing to customer loyalty. Quality can be perceived differently among people (Lovelock and Wirtz, 2011). Customer's judgement of the overall excellence or superiority of ceratin providers' performance is perceived as service quality (Qayyum, et.al, 2013). Chinomona and Sandada (2013) Identified two categories of quality service - technical and functional. The technical quality of the service refers to what is done to provide the service whereas the functional quality relates to how the service provided.

\subsection{Customer Satisfaction}

Customer satisfaction most commonly identified in service marketing literature as a key factor to customer loyalty (Qayyum, et.al, 2013). Satisfaction is one of the determinant to survive in the competition (Chinomona and Sandada, 2013). By keeping the customer satisfy, the company can keep the remain customer. Satisfaction is a combination of consumers' evaluation before buying product and their response about the service or the product after they buy the product (Adjei and Denanyoh, 2014).

\subsection{Customer Trust}

Trust is an act that shown by a person if they believe in something. Customer trust means that customers believe in a company because of their service or the product is reliable to them, customer will be confident to use the product or service if they trust it. "Trust is the eagerness of a party to be susceptible to the actions of another party with the hope that the action done by the other will be important to the trustor or grantor, irrespective of the ability of the trustor to monitor or control the other party" (Qayyum, et.al, 2013). 


\subsection{Customer Intimacy}

Customer intimacy is the customers' emotional attachment that chain them to the particular brands (Chinomona and Sandada, 2013). Companies usually use customer intimacy strategy to be customer-centric and their day-to-day operations are dictated by customer needs (Chinomona and Sandada, 2013). Intimate can also means as how often and how fun the communication between customer and provider.

\subsection{Customer Loyalty}

Loyalty has been defined as a very strong commitment to rebuy a product or service in the future despite situational influences and marketing efforts than can lead to cause switching behavior (Kotler and Keller, 2012). Customer loyalty is "a deeply held commitment to re-buy or re-patronize a preferred product/service consistently in the future, thereby causing a repetitive same brand purchasing, despite situational influences and marketing efforts having the potential to cause switching behavior (Khizindar, et.al., 2015).

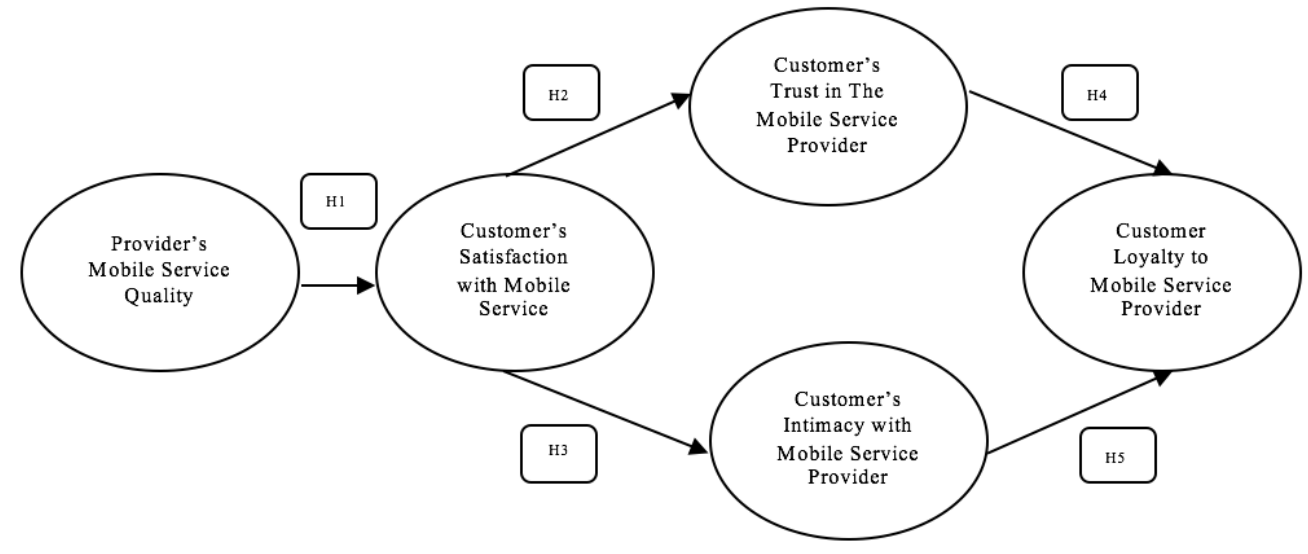

Figure 2.1 Theoretical Framework

Source: Chinomona \& Sandada (2013)

This study conducted to know whether there is a positive influence on service quality and customer satisfaction through customer trust and customer intimacy regarding customer loyalty towards mobile service provider in Indonesia. The hypotheses from this study can be seen in the table below.

Table 2.1 Hypotheses

\begin{tabular}{|l|l|}
\hline H1 & $\begin{array}{l}\text { High levels of service quality provided by the mobile service provider positively } \\
\text { influence customer's satisfaction. }\end{array}$ \\
\hline H2 & $\begin{array}{l}\text { Customers' satisfaction with the quality of mobile service positively influence } \\
\text { customer's trust with the mobile service provider. }\end{array}$ \\
\hline H3 & $\begin{array}{l}\text { Customers' satisfaction with the quality of mobile service positively influence } \\
\text { customer's intimacy with the mobile service provider. }\end{array}$ \\
\hline H4 & $\begin{array}{l}\text { Customers' trust with the mobile service provider positively influence customers' } \\
\text { loyalty to the mobile service provider. }\end{array}$ \\
\hline H5 & $\begin{array}{l}\text { Customers' Intimacy with the provider positively influence customers' loyalty to the } \\
\text { mobile service provider. }\end{array}$ \\
\hline
\end{tabular}

Source: Data is processed by the research team 


\section{RESEARCH METHOD}

To test the hypotheses the writer gathering 400 samples that can be get by using Slovin's Formula:

$n=\frac{N}{1+N e^{2}}$

Where:

$\mathrm{n}=$ Sample Size

$\mathrm{N}=$ Population Size (256.830.000)

$1=$ Constant Value

$\mathrm{e}=$ Error $(5 \%)$

To analyze the data, the writer used Smart PLS 3.2.7 for Mac. There are two stages for analyzing data in PLS, outer model and inner model. Outer model is the equation model to find out the validity and reliability model through algorithm iteration, parameter measurement model, and $\mathrm{R}^{2}$. The next one is inner model which is a structural model to predict causality relation among latent variables (Abdillah and Jogiyanto, 2015).

\section{IV.DISCUSSION}

For 5\% error, the hypotheses will be accepted if the value is above 1.65 . The result is shown by the table below.

Table 4.1. Hypotheses Testing Result

\begin{tabular}{|c|c|c|c|c|c|}
\hline Hypotheses & Path & $\begin{array}{c}\text { Path } \\
\text { Coefficient }\end{array}$ & $\begin{array}{c}\text { t-statistic } \\
\text { value }\end{array}$ & P Values & Description \\
\hline H1 & SQ -> CS & 0.759 & 25.147 & 0.000 & Accepted \\
\hline H2 & CS -> CI & 0.721 & 23.677 & 0.000 & Accepted \\
\hline H3 & CS -> CT & 0.855 & 33.551 & 0.000 & Accepted \\
\hline H4 & CT -> CL & 0.553 & 11.068 & 0.000 & Accepted \\
\hline H5 & CI -> CL & 0.250 & 5.278 & 0.000 & Accepted \\
\hline
\end{tabular}

Source: Data is processed by the research team

The results of the hypotheses testing show that all the hypotheses are accepted because all of them have t-value above 1.65 (Indrawati, 2015). This means that service quality and customer satisfaction has a positive influence on customer loyalty towards mobile service provider in Indonesia. As we can see on the Table 4.1. that customer satisfaction to customer trust has the biggest path coefficient and t-value of 0.855 and 33.551 , it means that customer satisfaction through customer trust has the biggest influence on customer loyalty. This hypothesis also means that if the customer is satisfied with the mobile service provider they will more likely to trust them and it will lead to loyalty. 
Jurnal Manajemen dan Bisnis: Performa Volume XV Nomor 2 September 2018

\section{CONLUSION AND SUGGESTION}

\subsection{Conclusion}

According to the result from the test using smart PLS 3, the result can be conclude:

1. After doing some test from the questionnaire result using smart PLS 3, service quality through customer satisfaction, customer trust, and customer intimacy has a positive influence on customer loyalty.

2. After doing some test from the questionnaire result using smart PLS 3, customer satisfaction through customer trust and customer intimacy has a positive influence on customer loyalty.

3. After doing some test from the questionnaire result using smart PLS 3, customer trust has a positive influence on customer loyalty.

4. After doing some test from the questionnaire result using smart PLS 3, customer intimacy has a positive influence on customer loyalty.

5. Customer satisfaction through customer trust has the biggest influence on Customer Loyalty towards mobile service provider in Indonesia with t-statistics value of 33.551 and path coefficient of 0.855 .

\subsection{Suggestion}

\subsubsection{Suggestion for the company}

Based on the conclusion above, here are some of the suggestion for mobile service provider companies:

1. Companies should be trustful so that the customer can be loyal to them because customer trust is one of the dimension that has a positive influence. The companies only need to maintain customer trust with always keep their promises and it will be impact to the customer loyalty.

2. Companies should be able to satisfy the customers to make them loyal by provide a good service to the customers and fixed the problem that faced by the customer speedily. Companies should be able to maintain this dimension because this dimension will lead the customer to loyalty.

3. Companies should provide customer with the best service quality. Companies should increase their quality standards on every interaction, such as giving customers a clear explanation on every question that customers asked.

4. Companies and their customer should be care of their customers, so that the customer will feel intimacy towards their mobile service provider. Companies need to increase their concern for their customer to make them loyal.

\subsubsection{Suggestion for further research}

In this study, the dimensions that use are service quality, customer satisfaction, customer trust, customer intimacy that impacted to customer loyalty and all of the dimension are positively influence customer loyalty, but there are a lot of factors that are not mentioned in this study that probably have a positive influence towards customer loyalty such as price, promotion, and corporate image. Further research should be able to add some of the dimension that may have a positive influence towards customer loyalty. Further research also must maintain the sample gathering with using quota sampling so it will be a balance result between the places and the providers. 


\section{REFERENCES}

Abdillah, W., \& Jogiyanto. (2015). Partial Least Square (PLS). Yogyakarta, Indonesia: C.V ANDI OFFSET.

Adjei, K., \& Denanyoh, R. (2014, January). Determinants of Customer Loyalty among Mobile Telecom Subscribers in the Brong Ahafo. International Journal of Business and Social Research (IJBSR), 4(1), 82-95.

Buol, R. A. (2017, October 14). DATA: Jumlah Kartu Telepon Seluler Menurut Operator. Retrieved February 25, 2018, from zonautara: http://zonautara.com/blog/2017/10/14/datajumlah-kartu-telepon-seluler-menurut-operator/

Chinomona, R., \& Sandada, M. (2013). Predictors Of Customer Loyalty To Mobile Service Provider In South Africa. International Business \& Economics Research Journal, 12, 1631-1644.

ICLG. (2017). Telecoms, Media \& Internet 2017. Retrieved 2017, from Global Legal Group Limited: $\quad$ https://iclg.com/practice-areas/telecoms-media-and-internet-laws/telecomsmedia-and-internet-2017/indonesia

Indrawati. (2015). Metode Penelitian Manajemen dan Bisnis Konvergensi Teknologi Komunikasi dan Informasi. (D. Sumayyah, Ed.) Bandung, West Java, Indonesia: PT Refika Aditama.

Katadata. (2016). Telkomsel Raja Operator Seluler di Indonesia. Retrieved September 2017, from databoks.katadata.co.id: http://databoks.katadata.co.id/datapublish/2016/08/31/telkomsel-raja-operator-seluler-diindonesia

Khizindar, T. M., Al-Azzam, A. F., \& Khanfar, I. A. (2015). AN EMPIRICAL STUDY OF FACTORS AFFECTING CUSTOMER LOYALTY OF TELECOMMUNICATION INDUSTRY IN THE KINGDOM OF SAUDI ARABIA . British Journal of Marketing Studies, 98-115.

Kotler, P., \& Keller, K. L. (2012). Marketing Management. London, UK: Pearson Education.

Lovelock, C., \& Wirtz, J. (2011). Services Marketing People, Technology, Strategy. New Jersey, USA: Pearson.

Qayyum, A., Khang, D. B., \& Krairit, D. (2013). An analysis of the antecedents of loyalty and the moderating role of customer demographics in an emerging mobile phone industry. International Journal of Emerging Markets, 373-391.

TeknoRus. (2017, August 15). Daftar Paket Tarif Internet Termurah All Operator. Retrieved September 27, 2017, from TeknoRus: https://teknorus.com/ini-perbandingan-tarifinternet-termurah-semua-operator-di-indonesia/ 